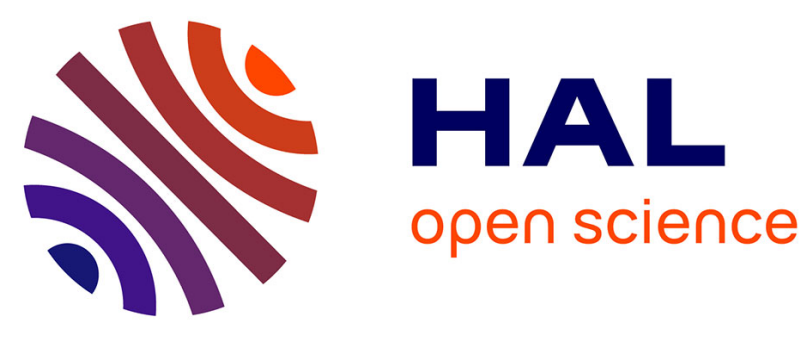

\title{
Copper exchanged FAU nanozeolite as non-toxic nitric oxide and carbon dioxide gas carrier
}

Kamila Goldyn, Clément Anfray, Sarah Komatya, Valerie Ruaux, Charly

Hélaine, Richard Retoux, Samuel Valable, Valentin Valtchev, Svetlana

Mintova

\section{To cite this version:}

Kamila Goldyn, Clément Anfray, Sarah Komatya, Valerie Ruaux, Charly Hélaine, et al.. Copper exchanged FAU nanozeolite as non-toxic nitric oxide and carbon dioxide gas carrier. Microporous and Mesoporous Materials, 2019, 280, pp.271-276. 10.1016/j.micromeso.2019.02.022 . hal-03027970

HAL Id: hal-03027970

https://hal-normandie-univ.archives-ouvertes.fr/hal-03027970

Submitted on 27 Nov 2020

HAL is a multi-disciplinary open access archive for the deposit and dissemination of scientific research documents, whether they are published or not. The documents may come from teaching and research institutions in France or abroad, or from public or private research centers.
L'archive ouverte pluridisciplinaire HAL, est destinée au dépôt et à la diffusion de documents scientifiques de niveau recherche, publiés ou non, émanant des établissements d'enseignement et de recherche français ou étrangers, des laboratoires publics ou privés. 


\title{
Copper exchanged FAU nanozeolite as non-toxic nitric oxide and carbon dioxide gas carrier
}

\author{
Kamila Goldyn ${ }^{a}$, Clément Anfray ${ }^{b \ddagger}$, Sarah Komaty a , Valerie Ruaux ${ }^{a}$, Charly Hélaine ${ }^{b}$, \\ Richard Retoux $^{c}$, Samuel Valable ${ }^{\mathrm{b}}$, Valentin Valtchev ${ }^{\mathrm{a}}$ and Svetlana Mintova ${ }^{\mathrm{a}}$ \\ a. Normandie Univ, ENSICAEN, CNRS, Laboratoire Catalyse et Spectrochimie, 14000 \\ Caen, France \\ b. Normandie Univ, CEA, CNRS, GIP CYCERON, ISTCT/CERVOxy group, 14000 \\ Caen, France \\ c. Normandie Univ, ENSICAEN, CNRS, CRISMAT, 14000 Caen, France
}

\begin{abstract}
A growing interest is currently directed to find an efficient $\mathrm{NO}$ and $\mathrm{CO}_{2}$ gas carriers for biomedical applications. The gas adsorption properties of sodium- $(\mathrm{Na}-\mathrm{X})$ and copper$(\mathrm{Cu}-\mathrm{X})$ containing FAU nanozeolite towards nitric oxide and carbon dioxide were studied. The materials were fully characterised by XRD, TEM, ICP, DLS and in-situ FTIR. The as-prepared Na-X showed higher gas adsorption ability towards carbon dioxide, whereas the ion-exchanged $\mathrm{Cu}-\mathrm{X}$ was more efficient adsorbent with regards to nitric oxide. In addition, the cytotoxicity tests disclosed that both nanozeolites have no toxicity making them suitable for further tests in biomedical field as gas transporters.
\end{abstract}

Keywords: Metal-exchanged nanozeolites, gas adsorption, non-toxic, gas carrier, biomedical applications 


\section{Introduction}

The well-established activity of copper containing zeolites with nitric oxide (NO) and carbon dioxide $\left(\mathrm{CO}_{2}\right)$ have proved their functionality mainly as a de-NOx catalyst, where the zeolites are used to perform selective catalytic reduction of nitric oxide (NO) [1-3], as well as $\mathrm{CO}_{2}$ adsorbent for gas separation in industrial and environmental processes $[4,5]$. Based on this background we develop new application where zeolites are employed to act as $\mathrm{NO}$ and $\mathrm{CO}_{2}$ gas carriers for potential biomedical applications.

$\mathrm{NO}$ is an antibacterial, principal signalling molecule (generated within the body), that is involved in many biological processes, namely regulation of the blood flow, neurotransmission and immune response [6-8]. $\mathrm{CO}_{2}$, also generated within the body as a result of aerobic respiration, is an essential moderator in human physiology, controlling blood circulation and $\mathrm{pH}$. The extrinsic delivery of such biologically active molecules is an interesting and challenging way of therapy that could potentially be an effective remedy for major illnesses. As an example, when $\mathrm{CO}_{2}$ is inhaled in the form of carbogen (mixture of $\mathrm{O}_{2} 95 \%$ and $5 \% \mathrm{CO}_{2}$ ), it increases tissue perfusion and oxygenation, which is an important stage in improving tumour treatment efficacy $[9,10]$. However, the broad range of effects generated in the body by these two gases raised an issue about its specificity and targeted delivery, which complicated the progress for their applications in biomedicine. Therefore, to overcome those uncertainties, the development of selective and most importantly non-toxic materials that can carry and release therapeutic gases is required.

Nowadays, there is a growing interest in finding suitable $\mathrm{NO}$ carriers to prevent perilous life conditions such as thrombosis (blood clot formation), at the surface of artificial blood vessels and medical devices. Currently, anticoagulants such as heparin 
are employed to overcome thrombosis, however, the use of latter can cause unexpected bleeding in other parts of the body, leading to loss of platelets and thus thrombocytopenia [11]. In the case of carbogen administration, the inhalation via nasal cannula or facemask showed insufficiency on tissue reoxygenation regarding progressive response to radio therapy [12]. As a result, a vast number of $\mathrm{NO}-$ and $\mathrm{CO}_{2}-$ carrying materials have been proposed, which are mainly based on synthetic polymers (PVC, PDMS) and fumed silica particles. For NO delivery purposes those materials have been functionalised with various amines, and upon reaction with NO, they form diazeniumdiolate ions. The latter, can hydrolyse in aqueous solution with suitable $\mathrm{pH}$ to release nitric oxide and thus act as a gas donor [13-17]. Over the years, it was demonstrated, namely by the group of Morris et al. that metal exchanged, highly crystalline porous materials, such as zeolites and metal organic framework (MOFs) type materials have the ability to adsorb and release nitric oxide [18-21]. The adsorption of $\mathrm{CO}_{2}$ in zeolites was also studied widely and demonstrated they can be used for an efficient gas storage and delivery for both environmental and biomedical applications $[18,22-24]$. The characteristics of zeolites namely, well-defined porous structures, high specific surface area, and chemical/thermal stability render them as appropriate materials for selective gas adsorption purposes [25,26]. Additionally, the chemical properties of zeolites, enable to control the gas adsorption capacity, which can be accomplished by tuning the zeolite composition, in terms of the type of metal ion present in the structure. The introduction of various cations $\left(\mathrm{Fe}^{3+}, \mathrm{Ce}^{3+} \mathrm{Cu}^{2+}, \mathrm{Gd}^{3+}\right)$ in the zeolite is usually achieved via post-synthetic ion-exchange, to further functionalise the material for targeted application [27,28]. Other aspects influencing the gas sorption 
affinity are the zeolite physical features, such as size and framework type (more than 239), providing a great array of structures to choose from depending on desired use.

The low toxicity of zeolite plays a major role when it comes to biomedical applications. The modifications of zeolite crystal size, from micron to nanoscale, as well as the development of template-free synthesis, yielding biocompatible nanozeolites becomes of important research field. The cytotoxicity of nanozeolites does not just depend on crystal size but also on particle agglomeration and stability in colloidal suspension [29]. As a result of their low toxicity towards sensitive cells (such as cells from the central nervous system), nanocrystals have drawn particular attention of researches working in the field of biomedical science, especially for contrast agents, controlled drug release [30-32], and gas delivery purposes [28,33,34]. Moreover, it has recently been reported that the copper containing FAU nanozeolite (in form of stable suspension), can be used for direct sanitisation of medical surfaces against ESKAPE bacteria and thus act as antimicrobial agent to prevent life-threatening infections.[35]

Here, we report the preparation of sodium and copper containing FAU-type nanozeolite (zeolite $\mathrm{X}$ ) with high sorption capacity towards $\mathrm{NO}$ and $\mathrm{CO}_{2}$, which can be used as alternative way of gas delivery for biomedical applications. The sorption affinity of as prepared $\mathrm{Na}$ - containing FAU $(\mathrm{Na}-\mathrm{X})$ and $\mathrm{Cu}$ ion-exchanged zeolite $(\mathrm{Cu}-$ $\mathrm{X})$ to $\mathrm{NO}$ and $\mathrm{CO}_{2}$ was studied by in-situ IR spectroscopy. Moreover, the cytotoxicity tests using a selection of cells, including, human tumour, kidney and most sensitive primary culture of astrocytes to assess the biocompatibility of prepared nanozeolites were performed. We also demonstrated that the cation types in zeolites highly affect the gas adsorption properties, i.e., the $\mathrm{Cu}-\mathrm{X}$ has greater adsorption capacity towards $\mathrm{NO}$, whereas the as prepared $\mathrm{Na}-\mathrm{X}$ has higher $\mathrm{CO}_{2}$ sorption affinity. The high sorption 
capacity of non-toxic $\mathrm{Cu}-\mathrm{X}$, combined with antimicrobial properties, provide a platform for alternative therapies in the biomedical field.

\section{Experimental}

\subsection{Preparation of Cu-FAU nanozeolite}

The template-free, nanosized $\mathrm{Na}-\mathrm{X}$ zeolite with FAU framework topology was synthesised following a previously reported procedure [36]. The aluminate solution consisted of $2.5 \mathrm{~g}$ of sodium hydroxide $(\mathrm{NaOH}, 97 \%$, Sima-Aldrich) which was dissolved in $3.0 \mathrm{~g}$ double distilled water $\left(\mathrm{dd}_{2} \mathrm{O}\right)$, followed by slow addition of $0.297 \mathrm{~g}$ aluminum powder (325 mesh, 99.5\%, Alfa Aesar). The mixture was stirred until a clear solution was obtained. The silicate solution was prepared by dissolving $1.1 \mathrm{~g}$ of $\mathrm{NaOH}$ in $1.0 \mathrm{~g}$ of $\mathrm{dd} \mathrm{H}_{2} \mathrm{O}$, followed by the addition of $10 \mathrm{~g}$ colloidal silica (Ludox-HS 30, 30 wt $\% \mathrm{SiO}_{2}$, Aldrich). The acquired white, turbid suspension was placed in the oven at $100{ }^{\circ} \mathrm{C}$ for 5 min to obtain a clear suspension. The aluminate solution was then added dropwise to the latter placed in an ice-bath under vigorous stirring. As a result, a clear suspension with the starting molar composition $9 \mathrm{Na}_{2} \mathrm{O}: 1.1 \mathrm{Al}_{2} \mathrm{O}_{3}: 10 \mathrm{SiO}_{2}: 122 \mathrm{H}_{2} \mathrm{O}$ was produced, then aged at room temperature for $24 \mathrm{~h}$, followed by dehydration (to adjust the $\mathrm{H}_{2} \mathrm{O}$ content to 45) and hydrothermal treatment at $50{ }^{\circ} \mathrm{C}$ for $26 \mathrm{~h}$. The crystalline product were recovered by centrifugation $(20000 \mathrm{rpm}, 25 \mathrm{~min})$ and purified by washing with dd $\mathrm{H}_{2} \mathrm{O}$ until reaching the $\mathrm{pH}=7$.

The $\mathrm{Cu}-\mathrm{X}$ was prepared by ion-exchange of $2.4 \mathrm{wt} \% \mathrm{Na}-\mathrm{X}$ suspension with $0.004 \mathrm{M}$ of copper nitrate $\left(\mathrm{Cu}\left(\mathrm{NO}_{3}\right)_{2} .9 \mathrm{H}_{2} \mathrm{O}\right)$ at room temperature for $1 \mathrm{~h}$ (zeolite to copper 
suspension ratio 1:5). The sample was washed three times by centrifugation (20000 rpm, $25 \mathrm{~min}$ ) and redispersed in $\mathrm{dd}_{2} \mathrm{O}$. The final $\mathrm{pH}$ of the $\mathrm{Cu}-\mathrm{X}$ suspension was 7.

\subsection{Characterisation}

The stability and particle size distribution of $\mathrm{Na}-\mathrm{X}$ and $\mathrm{Cu}-\mathrm{X}$ zeolite suspensions $(\mathrm{pH}=7)$ was determined by zeta potential and dynamic light scattering (DLS) respectively, using a Malvern Zetasizer Nano instrument. The crystal structure of the parent $\mathrm{Na}-\mathrm{X}$ and the ion-exchanged zeolite $\mathrm{Cu}-\mathrm{X}$ was determined by $\mathrm{X}$-ray diffraction. The analyses were performed with a PANalytical X'Pert PRO-MPD diffractometer with $\mathrm{Cu} \mathrm{K} \alpha$ radiation $(\lambda=1.5418 \AA)$. The samples were scanned in the $2 \theta$ range of $4-50^{\circ}$ with a step size of $0.016^{\circ}$. The size and morphology of zeolites were studied by scanning electron microscope (SEM, MIRA-LMH TESCAN) supplied with a field emission gun and a transmission electron microscopy (TEM, $200 \mathrm{kV}$ JEOL 2010 FEG). The elemental composition was determined by inductively coupled plasma-atomic emission spectroscopy (ICP-AES) using an OPTIMA 4300 DV (PerkinElmer) instrument.

The adsorption capacities of self-supported zeolites wafers $\left(2 \mathrm{~cm}^{2}\right.$ area, $\left.20 \mathrm{mg}\right)$ towards $\mathrm{NO}$ and $\mathrm{CO}_{2}$ were determined using Nicolet Magna 550-FTIR spectrometer $\left(4 \mathrm{~cm}^{-1}\right.$ optical resolution and 128 scans) equipped with MCT detector. Prior to the adsorption measurements, each sample was activated at $120{ }^{\circ} \mathrm{C}$ under oxygen for 4 hours, followed by evacuation at the same temperature. The sample was further heated for $4 \mathrm{~h}$ at $300{ }^{\circ} \mathrm{C}$ under vacuum (10-6 Torr). The $\mathrm{NO}$ and $\mathrm{CO}_{2}$ were adsorbed at room temperature using various amounts introduced in small volumes; 1-100 Torr for NO and 10-180 Torr for $\mathrm{CO}_{2}$. All spectra were normalised to the sample weight. 
2.3. Cytotoxicity tests: materials and methods

Cell lines: Human embryonic kidney (HEK 293) and human glioblastoma cells (U87MG), were cultured in DMEM (Sigma-Aldrich, France) prior the toxicity tests. The cell lines listed above were purchased from ATCC (Manassas, VA, USA) and maintained in culture at $37^{\circ} \mathrm{C}$ with $5 \% \mathrm{CO}_{2}$ and $95 \%$ humidity.

DMEM was supplemented with $10 \%$ foetal bovine serum (Eurobio, France), $2 \mathrm{mM}$ glutamine (Sigma-Aldrich, France) and $100 \mathrm{U} / \mathrm{ml}$ penicillin/streptomycin (SigmaAldrich, France).

Primary culture of astrocytes: Cerebral cortices (isolated from neonatal 1-3 days old mice, Swiss, CURB, France) were carefully stripped of the meninges and dissociated to generate a single-cell suspension. The cultures were left to grow in an incubator at 37 ${ }^{\circ} \mathrm{C}$ (humidified with $5 \% \mathrm{CO}_{2}$ to confluency up to 20 days) and supplemented with DMEM consisting of $10 \%$ foetal bovine serum (Eurobio, France), $10 \%$ horse serum (Eurobio, France), $2 \mathrm{mM}$ glutamine (Sigma-Aldrich, France) and $100 \mathrm{U} / \mathrm{ml}$ penicillin/streptomycin (Sigma-Aldrich, France) prior use.

Cells exposure to nanosized zeolites: Before to cells exposure the $\mathrm{Na}-\mathrm{X}$ and $\mathrm{Cu}-\mathrm{X}$ nanozeolites were diluted in culture medium at concentrations: $1,10,50$ or $100 \mu \mathrm{g} / \mathrm{ml}$ then added directly into the wells. Cells were exposed to nanozeolites for a period of 24 , 48 and $72 \mathrm{~h}$. The control tests were performed with distilled water under exactly the same conditions. 
Cells viability: Cells were seeded in 24 -wells plates to obtain $80 \%$ of confluence on the day of analysis and measured in compliance with manufacturer's manual (WST-1 assay, Roche, France).

\section{Results and discussion}

\subsection{Properties of prepared nanozeolites}

The synthesised Na-X nanosized zeolite sample is pure and highly crystalline (Figure $1(\mathrm{a}, \mathrm{b}, \mathrm{c})$. After ion-exchange with copper the framework structure of the sample $\mathrm{Cu}-\mathrm{X}$ is completely preserved. The $\mathrm{X}$-ray diffraction patterns of $\mathrm{Na}-\mathrm{X}$ and $\mathrm{Cu}-\mathrm{X}$ are alike in nature and typical for FAU-type zeolite. Figure 1a illustrates the Bragg peaks widening, which indicates the small size of zeolite crystals. The morphology of prepared samples was further assessed by TEM, which confirmed the nanosized particle size with mean diameter $<40 \mathrm{~nm}$ (Figure 1a and $\mathrm{b}$ ). The homogeneous nanocrystals exhibit a typical octahedral morphology with fully crystalline and well-developed faces, which remained unchanged after the incorporation of copper .

The elemental composition of the samples is presented in Table 1. The ion-exchange process does not influence the $\mathrm{Si} / \mathrm{Al}$ ratio, which was around 1.6 for both samples. Consequently, $59 \%$ of sodium was exchanged, leaving $5.11 \mathrm{wt} \%$ of copper present in the $\mathrm{Cu}-\mathrm{X}$ sample.

The stability of colloidal zeolite suspensions is one of the prime factors considered for biomedical applications. The stability of $\mathrm{Na}-\mathrm{X}$ and $\mathrm{Cu}-\mathrm{X}$ samples is determined by evaluating the zeta potential values. This technique measures the surface charge of nanoparticles and it is influenced by $\mathrm{pH} /$ concentration of the zeolite suspension. 
Generally, the zeta potential limit value of $\pm 30 \mathrm{mV}$ is employed to determine the stability of nanozeolites in suspension. The zeta potential values are $-43.1 \mathrm{mV}$ to -42.4 $\mathrm{mV}$ for $\mathrm{Na}-\mathrm{X}$ and $\mathrm{Cu}-\mathrm{X}$ nanozeolites, respectively, demonstrating the high colloidal stability of both zeolite suspensions (Figure 2a). In addition, DLS results show narrow, monomodal particle size distribution, which are similar for both samples (Figure $2 b$ ). This indicates that the ion-exchange does not influence the stability of zeolite nanocrystals.

Table 1. The elemental analysis of $\mathrm{Na}-\mathrm{X}$ and $\mathrm{Cu}-\mathrm{X}$ zeolites determined by ICP.

\begin{tabular}{cccccc}
\hline Sample name & $\begin{array}{c}\text { Na } \\
(\mathbf{w t .} \%)\end{array}$ & $\begin{array}{c}\mathbf{C u} \\
(\mathbf{w t .} \%)\end{array}$ & $\begin{array}{c}\text { Al } \\
(\mathbf{w t .} \%)\end{array}$ & $\begin{array}{c}\text { Si } \\
(\mathbf{w t .} \%)\end{array}$ & Si/Al \\
\hline $\mathrm{Na}-\mathrm{X}$ & 9.60 & - & 11.84 & 19.29 & 1.63 \\
$\mathrm{Cu}-\mathrm{X}$ & 5.69 & 5.11 & 11.38 & 17.86 & 1.57 \\
\hline
\end{tabular}

\subsection{In-situ FTIR measurements}

In-situ IR spectroscopy was used to determine the sorption capacity of as-prepared $\mathrm{Na}-\mathrm{X}$ and $\mathrm{Cu}-\mathrm{X}$ samples toward $\mathrm{NO}$ and $\mathrm{CO}_{2}$.

The adsorption of nitric oxide on zeolite samples after activation was performed at room temperature. The IR spectra of $\mathrm{NO}$ adsorbed on $\mathrm{Na}-\mathrm{X}$ and $\mathrm{Cu}-\mathrm{X}$ in the region of $1652-1260 \mathrm{~cm}^{-1}$ are presented in Figure 3. The spectra are similar with the exception of the bands at 1906 and $1883 \mathrm{~cm}^{-1}$ clearly observed in the $\mathrm{Cu}-\mathrm{X}$ sample (Figure 3b).

According to previous studies the bands positioned in the $1652-1260 \mathrm{~cm}^{-1}$ region correspond to surface species, in most cases nitrates, nitrites and nitro and/or nitrito compounds (Table 2) [37-40]. The bands at 1906 and $1883 \mathrm{~cm}^{-1}$ are attributed to 
nitrosyls, which are formed upon nitric oxide adsorption on two different $\mathrm{Cu}^{2+}$ sites, giving rise to formation of $\mathrm{Cu}^{2+}-\mathrm{NO}$ species. No bands at $1900 \mathrm{~cm}^{-1}$ was observed for pure Na-X nanozeolite.

The adsorption capacity of zeolites towards NO was evaluated by measuring the intensity of the bands in the region of $1906-1883 \mathrm{~cm}^{-1}$ at 100 Torr (Figure 4). The results indicated that copper-containing nanozeolite has greater NO capacity in comparison to the Na-X. This can be explained by the stronger interactions of NO with the copper by the formation of new adsorption sites for NO.

Table 2. Assignment of the IR bands observed after NO adsorption on Na- and Cu-X.[36,37]

\begin{tabular}{lll}
\hline IR bands $\mathbf{( c m}^{-1)}$ & Structure & Notes \\
\hline 1906 & NO on $\mathrm{Cu}^{2+}$ & on $\mathrm{Cu}^{2+}$ carrying extra lattice oxygen \\
1883 & $\mathrm{NO}$ on $\mathrm{Cu}^{2+}$ & on isolated $\mathrm{Cu}^{2+}$ moved to accessible position \\
$1652-1649$ & bridging nitrates & on Al sites \\
$1579-1554$ & monodentate nitrates & on Si sites \\
1486 & monodentate nitrate & - \\
1442 & monodentate nitrito & - \\
1404 & nitrate species & - \\
$1379-1353$ & Nitro species & - \\
1315 & Nitro/nitrate species & - \\
1260 & Nitro species & on Na sites \\
\hline
\end{tabular}

The adsorption of carbon dioxide was carried out at room temperature on the readily activated $\mathrm{Na}-$ and $\mathrm{Cu}-\mathrm{X}$ zeolite samples. Figure $5 \mathrm{a}, \mathrm{b}$ presents the evolution of FTIR spectra for $\mathrm{Na}-\mathrm{X}$ and $\mathrm{Cu}-\mathrm{X}$ nanozeolites. Two regions at $2400-2300 \mathrm{~cm}^{-1}$ and 1800 $1200 \mathrm{~cm}^{-1}$ were evaluated. These regions are characteristic for physisorbed and chemisorbed $\mathrm{CO}_{2}$ species, respectively. Accordingly, well-pronounced adsorption bands at $2353 \mathrm{~cm}^{-1}$ and $2350 \mathrm{~cm}^{-1}$ are present for $\mathrm{Na}-\mathrm{X}$ and $\mathrm{Cu}-\mathrm{X}$, which are ascribed to the 
asymmetric stretching mode of physically adsorbed carbon dioxide on the zeolite surface [41].

The band intensity increases with increasing gas pressure, therefore the amount of physisorbed $\mathrm{CO}_{2}$ was evaluated at constant pressure for both samples. The spectra of sodium and copper nanozeolites at 180 Torr are presented in Figure 6 (left). The physisorbed $\mathrm{CO}_{2}$ on the $\mathrm{Na}-\mathrm{X}$ sample is eight times higher than on the $\mathrm{Cu}-\mathrm{X}$ as shown in Figure 6 (right).

The less pronounced bands in the $1800-1200 \mathrm{~cm}^{-1}$ region are typical for carbonates [42]. These carbonate species include notably stable mono-, uni- and bidentate carbonates, which are formed as a result of $\mathrm{CO}_{2}$ interaction with the oxygen bridging aluminium or silicon atoms [43]. It was previously reported that the carbonate formation can limit carbon dioxide adsorption due to decrease of accessibility to zeolite surface [44]. In the copper-containing sample the carbonate region is not very prominent, this made it difficult to distinguish between different types of carbonates present. The amount of chemisorbed $\mathrm{CO}_{2}$ was measured at 180 Torr for $\mathrm{Na}-\mathrm{X}$ and $\mathrm{Cu}-\mathrm{X}$, showing that sodium-containing nanosized zeolite has three times greater adsorption capacity in contrast to the copper one (Figure 6). This result demonstrates that by simple ionexchange the properties of zeolite can be readily modified depending on the desired application. As mentioned before the adsorption of both gases was performed in the absence of water which simplified the measurements. However, when a very hydrophilic zeolite such as FAU is considered for a gas delivery in biological systems, the contact with water is unavoidable. Generally, the gas release in zeolites is stimulated by water diffusion, and other factors such as metal type, position and distribution in 
zeolites have to be considered. Therefore, the evaluation of gas adsorption in hydrated sample is a challenge that has to be taken into consideration for future studies.

\subsection{Cytotoxicity tests of nanosized $\mathrm{Na}-\mathrm{X}$ and $\mathrm{Cu}-\mathrm{X}$ zeolites}

In order to assess the biocompatibility of nanozeolites and thus prove their applicability in biomedicine, cytotoxicity measurements were performed. Different cell lines including human glioblastoma (U87-MG), human kidney (HEK 293) and mice astrocytes were exposed to zeolite samples at increasing concentrations $(1-100 \mu \mathrm{g} / \mathrm{ml})$ for 24-72 hours, followed by cell viability measurements. It is important to note that in some cases the cell viability is greater than $100 \%$ due to cell peroliferation (increase in cell number due to cell growth and division). As a result, no toxicity was observed for U87-MG cells which were subjected to both, $\mathrm{Na}-\mathrm{X}$ and $\mathrm{Cu}-\mathrm{X}$ nanosized zeolites (Figure 7) whatever the concentration used until $48 \mathrm{~h}$ of exposure. The only exception is a small decrease in cell viability after $72 \mathrm{hrs}$ of exposure to high concentration of coppercontaining nanozeolites.

Human kidney cells display slightly higher sensitivity towards nanozeolites (Figure 8). In general, both zeolites are harmless to the HEK 293 cells when exposed to low concentrations, however, a $40 \%$ decrease in cell viability was observed after $72 \mathrm{hrs}$ at $100 \mu \mathrm{g} / \mathrm{ml}$ of $\mathrm{Cu}-\mathrm{X}$. For astrocytes cell lines exposed to zeolite nanocrystals a dose dependant cell death is observed. The cell viability decreased by $\sim 43 \%$ after exposure to $50-100 \mu \mathrm{g} / \mathrm{ml}$ of zeolites as presented in Figure 9 . 


\section{Conclusions}

The sodium- and copper-containing nanosized FAU zeolite crystals ( $\mathrm{Na}-\mathrm{X}$ and $\mathrm{Cu}-$ X) were prepared in the form of stable colloidal suspensions. The gas adsorption properties of both materials towards nitric oxide and carbon dioxide were evaluated; the materials are considered to be used for potential gas delivery systems in biomedicine. The copper ion-exchanged nanozeolites $(\mathrm{Cu}-\mathrm{X})$ show increased $\mathrm{NO}$ adsorption capacity due to the formation of new adsorption sites of $\mathrm{NO}$ in comparison to the sodium form. On the other hand the $\mathrm{Na}-\mathrm{X}$ shows better adsorption affinity towards $\mathrm{CO}_{2}$. Both, Naand $\mathrm{Cu}-\mathrm{X}$ nanozeolites, show no cytotoxicity towards human glioblastoma, kidney and mice astrocytes, confirming their biocompatibility and thus ability to be further employed as gas carriers for biomedical applications.

\section{Acknowledgements}

This work was supported by the Institut National du Cancer (PLBIO17 INCA_11699) and Conseil Régional de Basse-Normandie (Projet Emergence ZEOXY) France ), and the European Union-Fonds Européen de Développement Régional (FEDER) 


\section{References}

[1] M. Iwamoto, S. Yokoo, K. Sakai, S. Kagawa, J. Chem. Soc. Faraday Trans. 1 Phys. Chem. Condens. Phases 77 (1981) 1629-1638.

[2] P. Ciambelli, P. Corbo, F. Migliardini, Catal. Today 59 (2000) 279-286.

[3] G. Delahay, S. Kieger, N. Tanchoux, P. Trens, B. Coq, Appl. Catal. B Environ. 52 (2004) 251-257.

[4] C. Boruban, E. Nalbant Esenturk, J. Mater. Res. 32 (2017) 3669-3678.

[5] M.R. Hudson, W.L. Queen, J.A. Mason, D.W. Fickel, R.F. Lobo, C.M. Brown, J. Am. Chem. Soc. 134 (2012) 1970-1973.

[6] P.A. Bachmann, P.L. Luisi, J. Lang, Nature 357 (1992) 57-59.

[7] V. Calabrese, C. Mancuso, M. Calvani, E. Rizzarelli, D.A. Butterfield, A.M. Giuffrida Stella, Nat. Rev. Neurosci. 8 (2007) 766-775.

[8] F.X. Guix, I. Uribesalgo, M. Coma, F.J. Muñoz, Prog. Neurobiol. 76 (2005) 126152.

[9] A. Chakhoyan, A. Corroyer-Dulmont, M.M. Leblond, A. Gérault, J. Toutain, L. Chazaviel, D. Divoux, E. Petit, E.T. MacKenzie, F. Kauffmann, N. Delcroix, M. Bernaudin, O. Touzani, S. Valable, J. Cereb. Blood Flow Metab. 37 (2016) $2270-2282$.

[10] J.H. Kaanders, J. Bussink, A.J. Van der Kogel, Lancet Oncol. 3 (2002) 728-737.

[11] Z. Cai, S. V. Yarovoi, Z. Zhu, L. Rauova, V. Hayes, T. Lebedeva, Q. Liu, M. Poncz, G. Arepally, D.B. Cines, M.I. Greene, Nat. Commun. 6 (2015) 1-10.

[12] R.W.M. van der Maazen, H.O.M. Thijssen, J.H.A.M. Kaanders, A. de Koster, A. Keyser, M.J.J. Prick, J.A. Grotenhuis, P. Wesseling, A.J. van der Kogel, Radiother. Oncol. 35 (1995) 118-122. 
[13] R.S. Drago, B.R. Karstetter, J. Am. Chem. Soc. 83 (1961) 1819-1822.

[14] K.M. Davies, D.A. Wink, J.E. Saavedra, L.K. Keefer, J. Am. Chem. Soc. 123 (2001) 5473-5481.

[15] D.J. Smith, D. Chakravarthy, S. Pulfer, M.L. Simmons, J.A. Hrabie, M.L. Citro, J.E. Saavedra, K.M. Davies, T.C. Hutsell, D.L. Mooradian, S.R. Hanson, L.K. Keefer, J. Med. Chem. 39 (1996) 1148-1156.

[16] H. Zhang, G.M. Annich, J. Miskulin, K. Stankiewicz, K. Osterholzer, S.I. Merz, R.H. Bartlett, M.E. Meyerhoff, J. Am. Chem. Soc. 125 (2003) 5015-5024.

[17] H. Zhang, G.M. Annich, J. Miskulin, K. Osterholzer, S.I. Merz, R.H. Bartlett, M.E. Meyerhoff, Biomaterials 23 (2002) 1485-1494.

[18] R.E. Morris, P.S. Wheatley, Angew. Chemie - Int. Ed. 47 (2008) 4966-4981.

[19] A.C. McKinlay, J.F. Eubank, S. Wuttke, B. Xiao, P.S. Wheatley, P. Bazin, J.C. Lavalley, M. Daturi, A. Vimont, G. De Weireld, P. Horcajada, C. Serre, R.E. Morris, Chem. Mater. 25 (2013) 1592-1599.

[20] S. Fox, T.S. Wilkinson, P.S. Wheatley, B. Xiao, R.E. Morris, A. Sutherland, A.J. Simpson, P.G. Barlow, A.R. Butler, I.L. Megson, A.G. Rossi, Acta Biomater. 6 (2010) 1515-1521.

[21] P.S. Wheatley, A.R. Butler, M.S. Crane, A.G. Rossi, I.L. Megson, R.E. Morris, Mol. Sieves From Basic Res. to Ind. Appl. Pts a B 158 (2005) 2033-2040.

[22] V. Georgieva, C. Anfray, R. Retoux, V. Valtchev, S. Valable, S. Mintova, Microporous Mesoporous Mater. 232 (2016) 256-263.

[23] L. Ohlin, P. Bazin, F. Thibault-Starzyk, J. Hedlund, M. Grahn, J. Phys. Chem. C 117 (2013) 16972-16982.

[24] G. Maurin, R. Bell, B. Kuchta, T. Poyet, P. Llewellyn, Adsorption 11 (2005) 
$331-336$.

[25] C. Martínez, A. Corma, Coord. Chem. Rev. 255 (2011) 1558-1580.

[26] M. Zaarour, B. Dong, I. Naydenova, R. Retoux, S. Mintova, Microporous Mesoporous Mater. 189 (2014) 11-21.

[27] V. Georgieva, C. Anfray, R. Retoux, V. Valtchev, S. Valable, S. Mintova, Microporous Mesoporous Mater. 232 (2016) 256-263.

[28] S. Komaty, C. Anfray, M. Zaarour, H. Awala, V. Ruaux, S. Valable, S. Mintova, Molecules 23 (2018) 37-48.

[29] C. Anfray, B. Dong, S. Komaty, S. Mintova, S. Valable, ACS Appl Mater Interfaces 9 (2017) 13849-13854.

[30] R. Amorim, N. Vilaça, O. Martinho, R.M. Reis, M. Sardo, J. Rocha, A.M. Fonseca, F. Baltazar, I.C. Neves, J. Phys. Chem. C 116 (2012) 25642-25650.

[31] D.G. Fatouros, D. Douroumis, V. Nikolakis, S. Ntais, A.M. Moschovi, V. Trivedi, B. Khima, M. Roldo, H. Nazar, P.A. Cox, J. Mater. Chem. 21 (2011) $7789-7794$

[32] N. Vilaça, A.F. Machado, F. Morais-Santos, R. Amorim, A. Patrícia Neto, E. Logodin, M.F.R. Pereira, M. Sardo, J. Rocha, P. Parpot, A.M. Fonseca, F. Baltazar, I.C. Neves, RSC Adv. 7 (2017) 13104-13111.

[33] S.E. Russell, J.M. González Carballo, C. Orellana-Tavra, D. Fairen-Jimenez, R.E. Morris, Dalt. Trans. 46 (2017) 3915-3920.

[34] P.S. Wheatley, A.R. Butler, M.S. Crane, S. Fox, B. Xiao, A.G. Rossi, I.L. Megson, R.E. Morris, J. Am. Chem. Soc. 128 (2006) 502-509.

[35] J. Redfern, K. Goldyn, J. Verran, R. Retoux, L. Tosheva, S. Mintova, Microporous Mesoporous Mater. 253 (2017) 233-238. 
[36] H. Awala, J.P. Gilson, R. Retoux, P. Boullay, J.M. Goupil, V. Valtchev, S. Mintova, Nat. Mater. 14 (2015) 447-451.

[37] M. Iwamoto, H. Yahiro, in: Handb. Zeolite Sci. Technol., New York (2003) 951997.

[38] M. Shelef, Chem. Rev. 95 (1995) 209-225.

[39] T. Venkov, K. Hadjiivanov, D. Klissurski, Phys. Chem. Chem. Phys. 4 (2002) $2443-2448$.

[40] K. Hadjiivanov, Catal. Rev. 42 (2000) 71-144.

[41] P. Galhotra, J.G. Navea, S.C. Larsen, V.H. Grassian, Energy Environ. Sci. 2 (2009) 401-409.

[42] J.W. Ward, H.W. Habgood, J. Phys. Chem. 70 (1966) 1178-1182.

[43] D. Bonenfant, M. Kharoune, P. Niquette, M. Mimeault, R. Hausler, Sci. Technol. Adv. Mater. 9 (2008) 1-7.

[44] C.L. Angell, M. V Howell, J. Phys. Chem. 47 (1969) 3831-3836. 


\section{Figure captions:}

Figure 1. (a) XRD patterns of samples $\mathrm{Na}-\mathrm{X}$ and $\mathrm{Cu}-\mathrm{X}$, and TEM images of (b) Na-X and (c) $\mathrm{Cu}-\mathrm{X}$.

Figure 2. (a) Zeta potential and (b) DLS curves for $\mathrm{Na}-\mathrm{X}$ and $\mathrm{Cu}-\mathrm{X}$ zeolite suspensions.

Figure 3. FTIR spectra evolution of $\mathrm{NO}$ adsorbed on (a) $\mathrm{Na}-\mathrm{X}$ and (b) $\mathrm{Cu}-\mathrm{X}$ nanozeolites at gas pressure varying from 1 to 100 Torr.

Figure 4. FTIR bands after NO adsorption on Na-X (black) and $\mathrm{Cu}-\mathrm{X}$ (blue) at 100 Torr in the range $2075-1225 \mathrm{~cm}^{-1}$.

Figure 5. FTIR spectra evolution after carbon dioxide adsorption on (a) Na-X and (b) $\mathrm{Cu}-\mathrm{X}$ nanosized zeolites at room temperature.

Figure 6. FTIR spectra after carbon dioxide adsorption at 180 Torr (left) and CO2 adsorption capacity for $\mathrm{Na}$ - and $\mathrm{Cu}-\mathrm{X}$ zeolite samples measured at 180 Torr (right).

Figure 7. (a) Representative photographs of U87-MG cells after 24 hrs exposure to 10 $\mu \mathrm{g} / \mathrm{ml}$ of $\mathrm{Na}-\mathrm{X}, \mathrm{Cu}-\mathrm{X}$ zeolites and control $\left(\mathrm{H}_{2} \mathrm{O}\right)$, scale bar $=100 \mu \mathrm{m}$. (b) Quantification of cell viability of human glioblastoma after 24,48 and $72 \mathrm{hrs}$ exposure to $\mathrm{Na}-\mathrm{X}$ and $\mathrm{Cu}-\mathrm{X}$ zeolites with four different concentrations. Cell viability was assessed using the WST-1 test. Mean SD. $\mathrm{n}=3$.

Figure 8. (a) Representative photographs of HEK 293 cells after 24 hrs exposure to $10 \mu \mathrm{g} / \mathrm{ml}$ of $\mathrm{Na}-\mathrm{X}, \mathrm{Cu}-\mathrm{X}$ zeolites and control $\left(\mathrm{H}_{2} \mathrm{O}\right)$, scale bar $=100 \mu \mathrm{m}$. (b) Quantification of cell viability of human glioblastoma after 24, 48 and 72 hrs exposure to $\mathrm{Na}-\mathrm{X}$ and $\mathrm{Cu}-\mathrm{X}$ zeolites with four different concentrations. Cell viability was assessed using the WST-1 test. Mean SD. $n=3$. 
Figure 9. (a) Representative photographs of astrocytes after $24 \mathrm{hrs}$ exposure to $10 \mu \mathrm{g} / \mathrm{ml}$ of $\mathrm{Na}-\mathrm{X}, \mathrm{Cu}-\mathrm{X}$ zeolites and control $\left(\mathrm{H}_{2} \mathrm{O}\right)$, scale bar $=100 \mu \mathrm{m}$. (b) Quantification of cell viability of mice astrocytes after 24,48 and $72 \mathrm{hrs}$ exposure to $\mathrm{Na}-\mathrm{X}$ and $\mathrm{Cu}-\mathrm{X}$ zeolites with four different concentrations. Cell viability was assessed using the WST-1 test. Mean SD. $n=3$. 

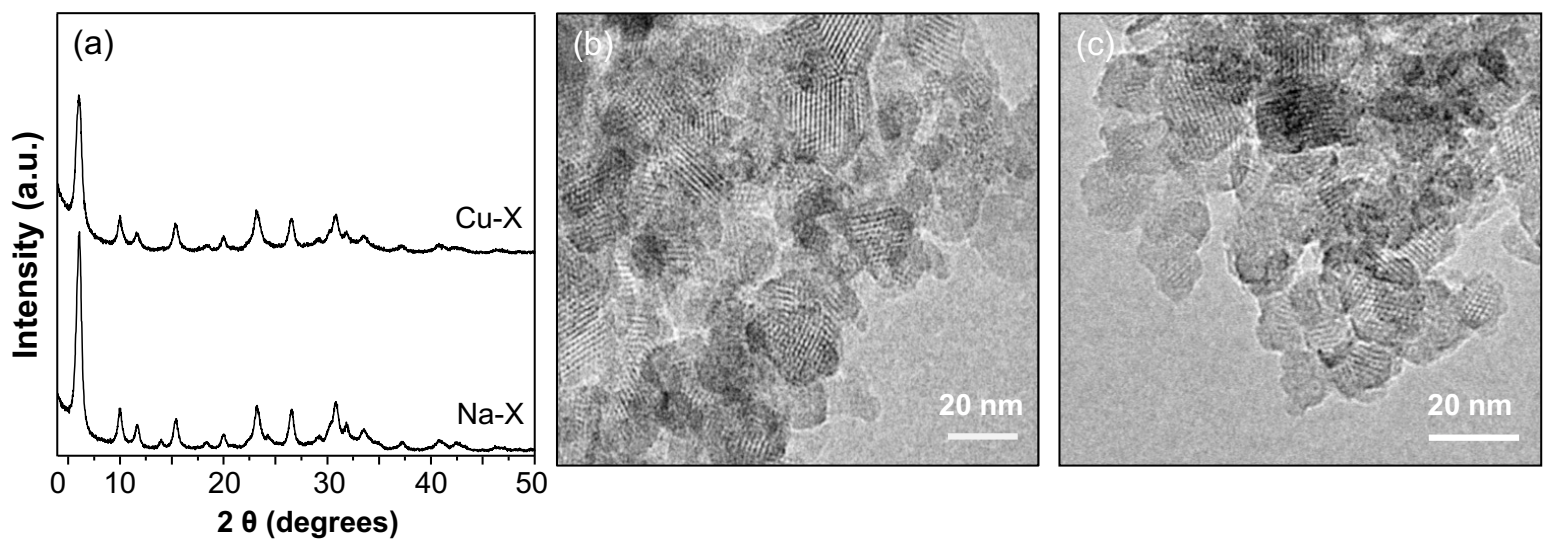

Figure 1 

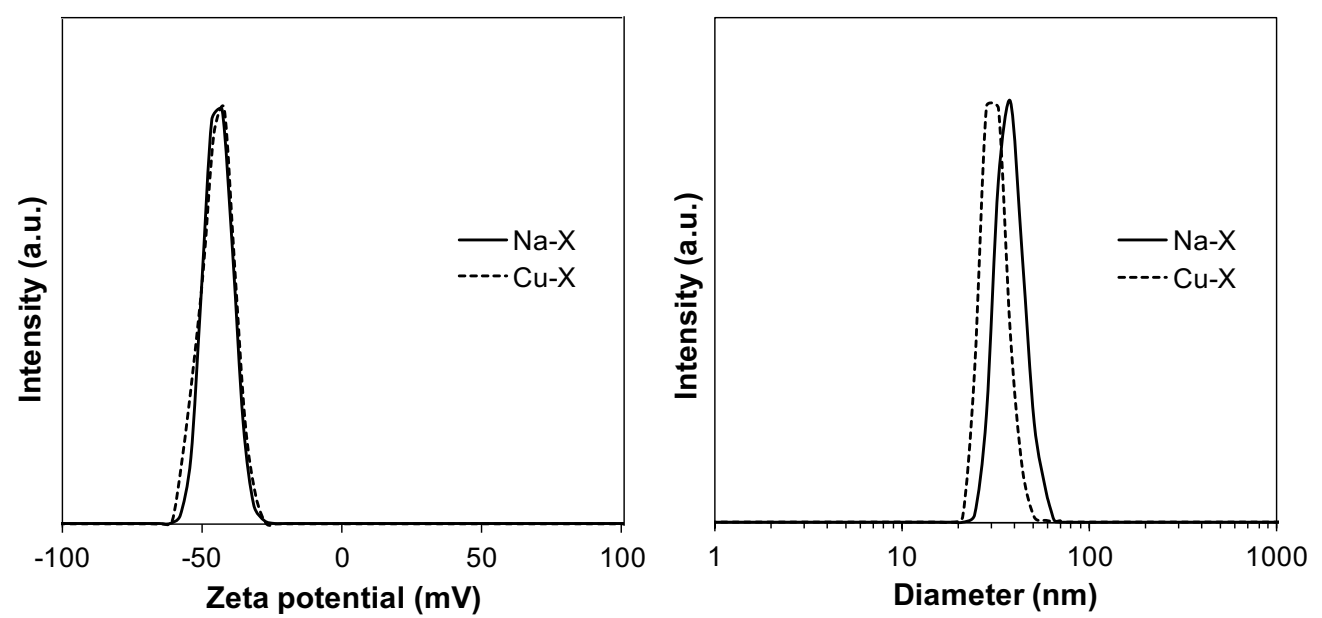

Figure 2 

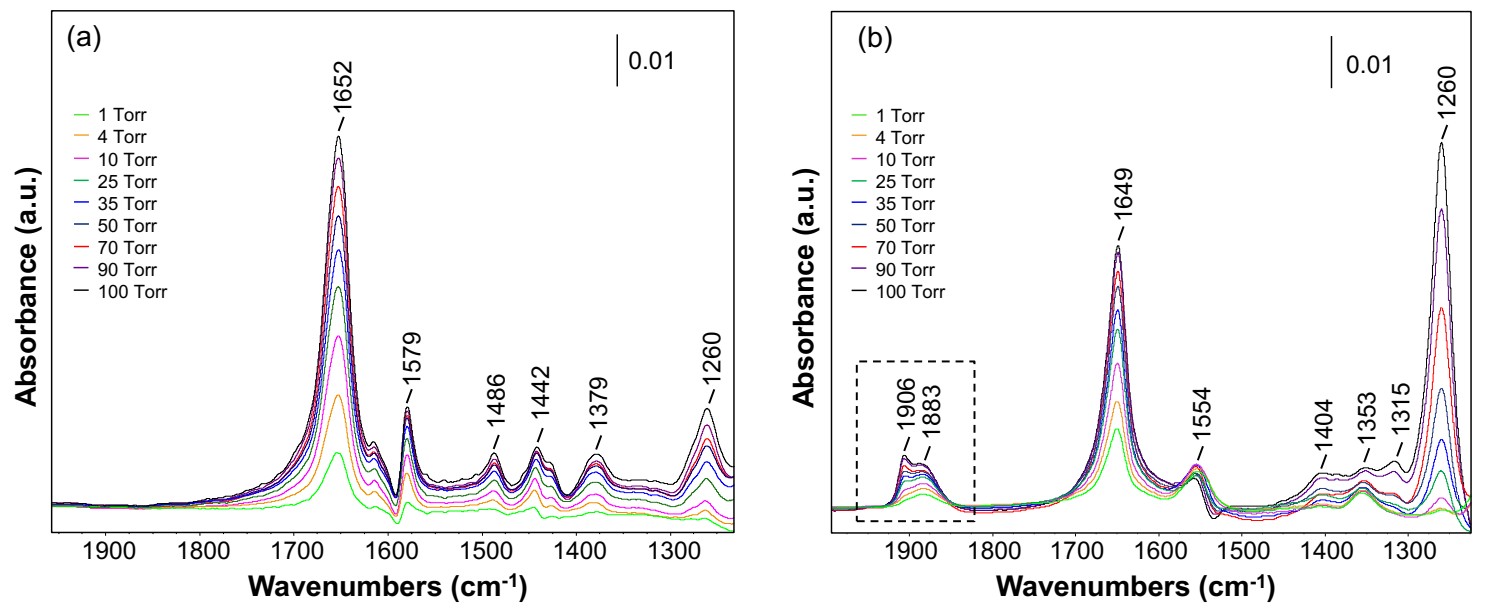

Figure 3 


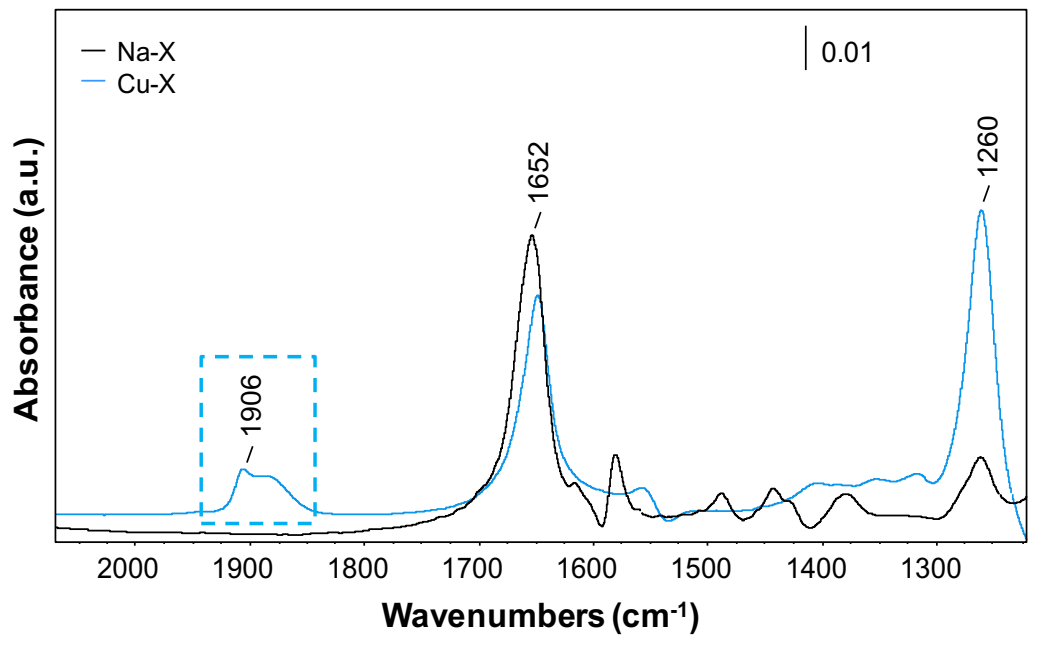

Figure 4 

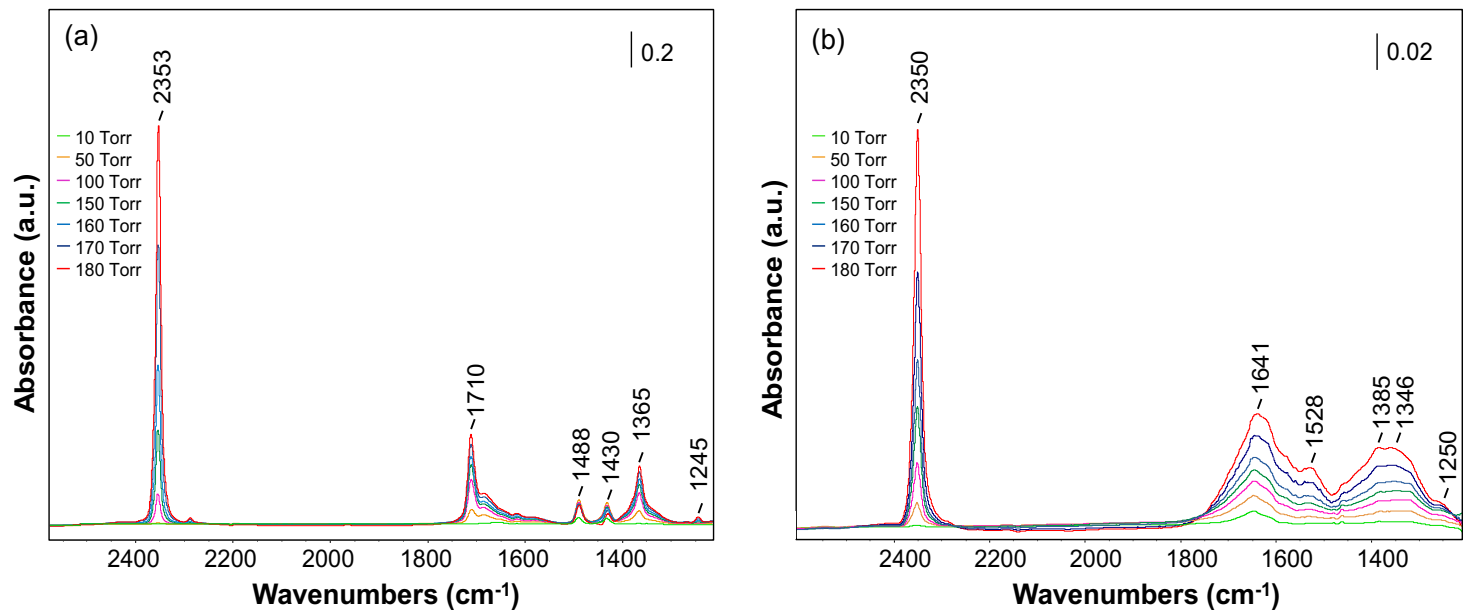

Figure 5 


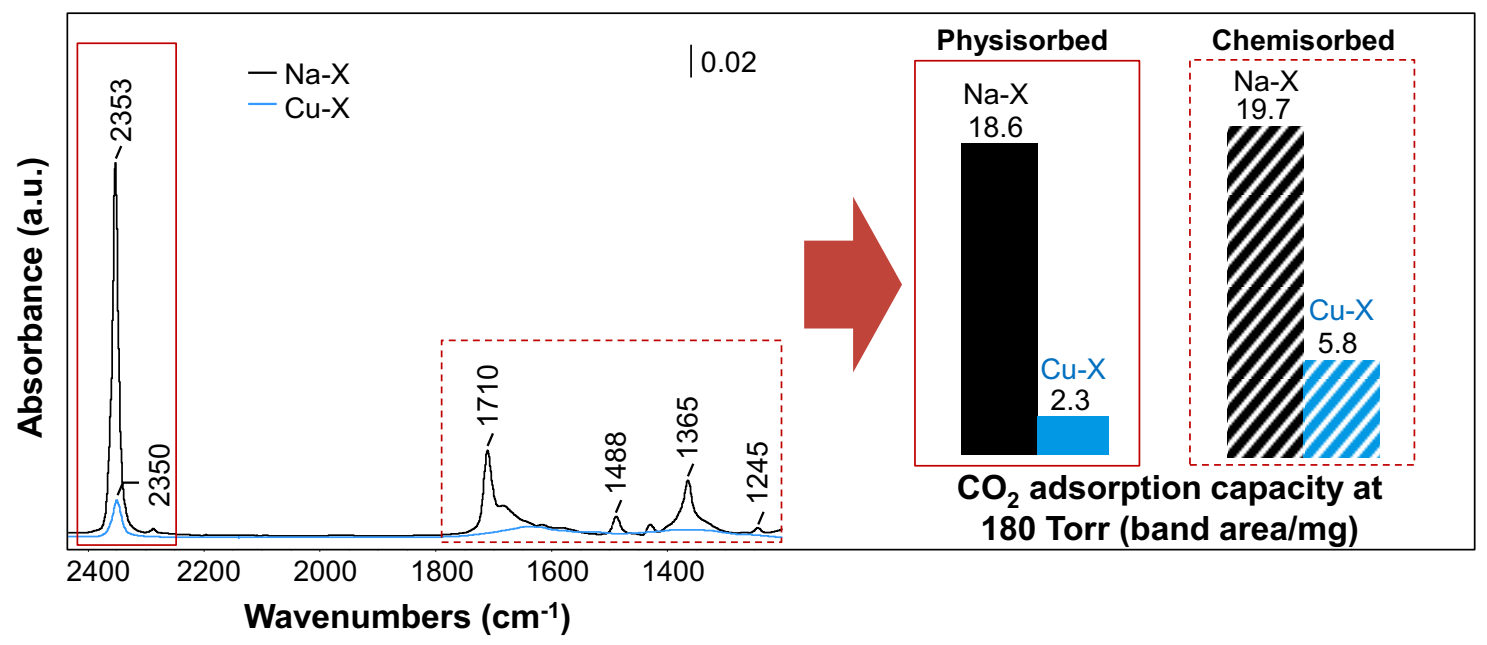

Figure 6 
(a)
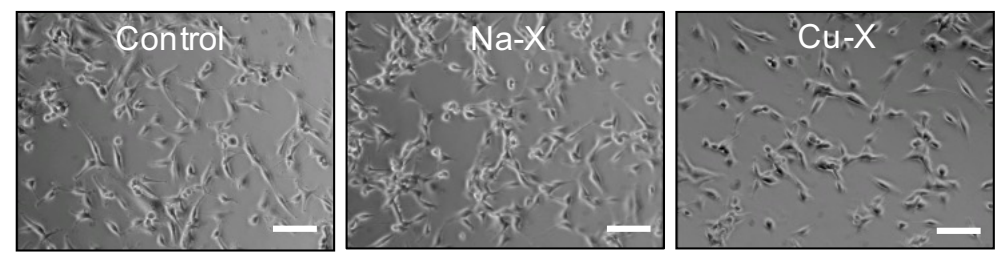

(b)

$\nabla 1 \mu \mathrm{g} / \mathrm{ml} \otimes 10 \mu \mathrm{g} / \mathrm{ml} \otimes 50 \mu \mathrm{g} / \mathrm{ml} \otimes 100 \mu \mathrm{g} / \mathrm{ml}$

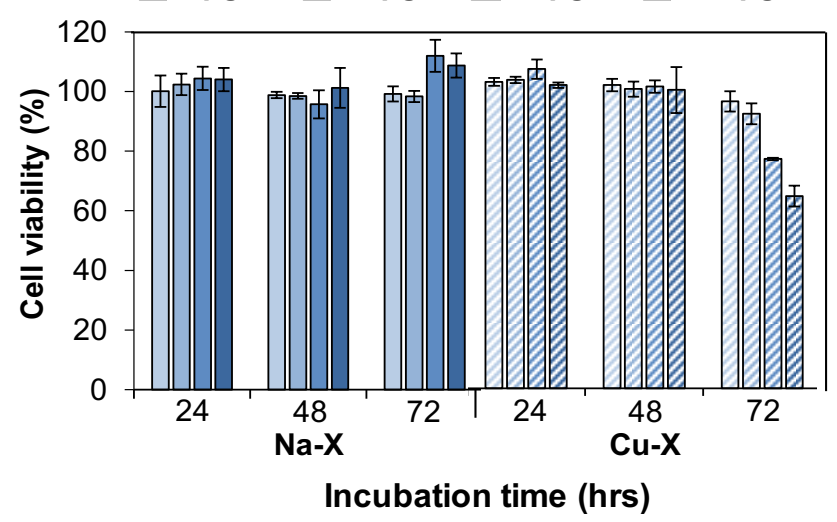

Figure 7 
(a)
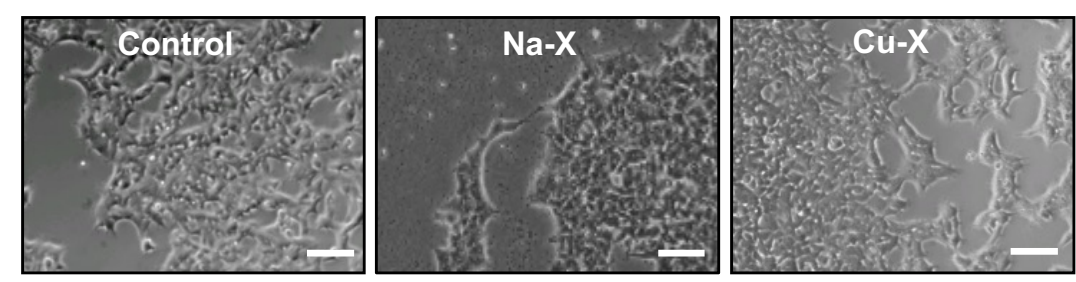

(b) $\quad \square 1 \mu \mathrm{g} / \mathrm{ml} \otimes 10 \mu \mathrm{g} / \mathrm{ml} \otimes 50 \mu \mathrm{g} / \mathrm{ml} \otimes 100 \mu \mathrm{g} / \mathrm{ml}$

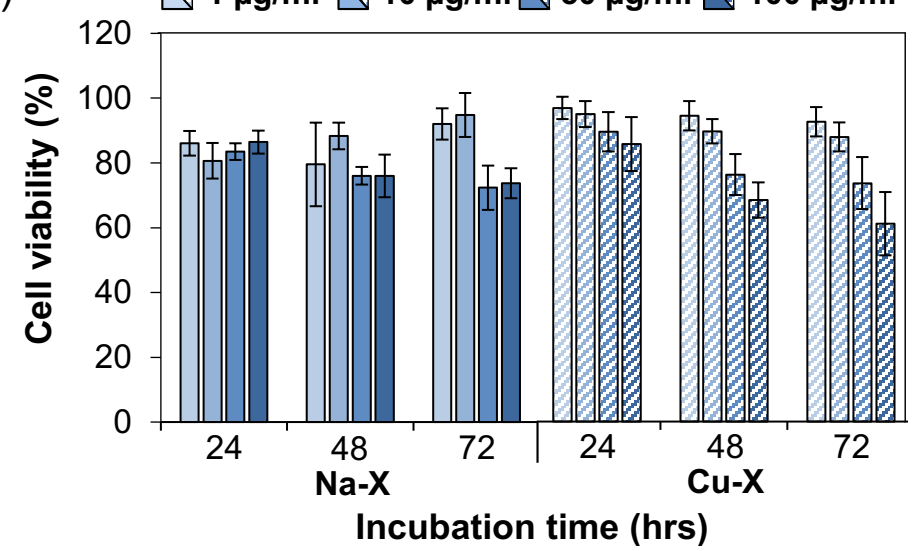

Figure 8 
(a)

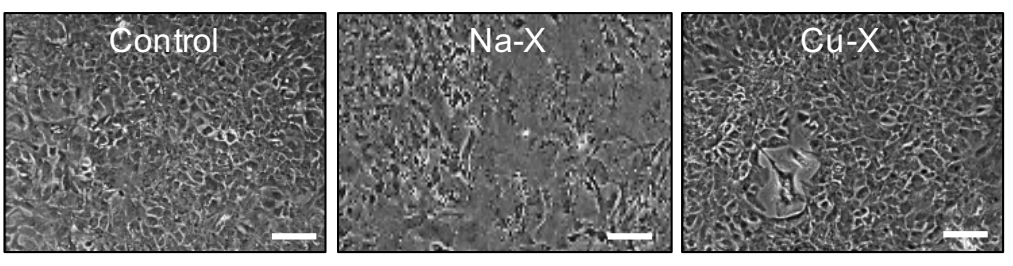

(b) $\quad \nabla 1 \mu \mathrm{g} / \mathrm{ml} \otimes 10 \mu \mathrm{g} / \mathrm{ml} \otimes 50 \mu \mathrm{g} / \mathrm{ml} \otimes 100 \mu \mathrm{g} / \mathrm{ml}$

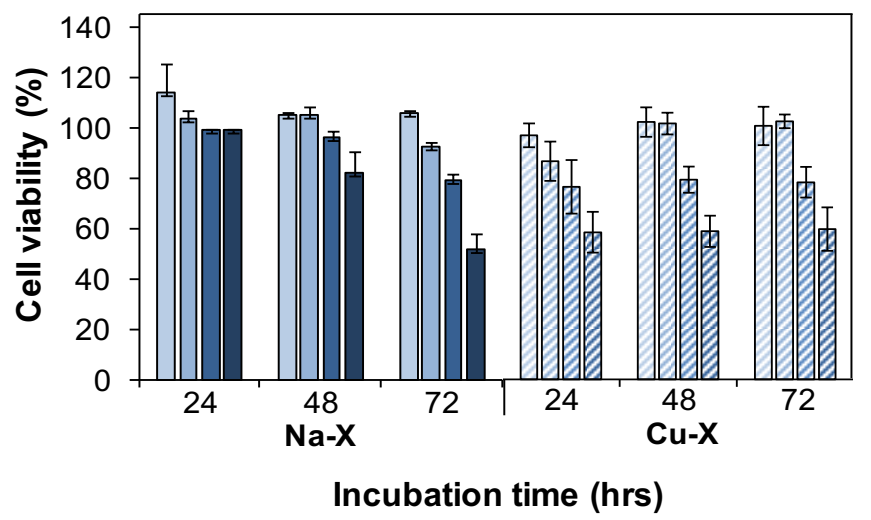

Figure 9 